\title{
WUJUD KIAS DALAM TAMBO MINANGKABAU
}

\author{
1Yendra, S. S., M. Hum \\ ${ }_{1}$ Program Studi Pendidikan Bahasa Inggris, STKIP PGRI Sumatera Barat, Indonesia \\ email: yendra_brutus@yahoo.com \\ Submitted :31-08-2016, Reviewed:31-08-2016, Accepted:31-08-2016 \\ http://dx.doi.org/10.22202/JG.2016.V2i2.736
}

\begin{abstract}
Research on kias in Tambo Minangkabau"s focused on the study of figurative forms and and forming figurative inspiration. This research aims to explain any forms of figurative and the inspiration forming figurative in Tambo Minangkabau. Based on the analysis conducted, figurative forms are identified into simile, metaphor, personification, alegori, parabel, sinekdoke, epitet, eponim, paranomasia, and antonomasia. Forms of figurative metaphors are identified form the most dominant form of variations convey stories in Tambo Minangkabau. Pattern conception of Minangkabau community built through forms and characteristic of nature that prefigured to all aspects to serve the teaching and philosophy of life and then poured into Tambo Minangkabau. Minangkabau people whose way of thinking is metaphorical. This is a manifestation of the philosophy of "Alam Takambang Jadi Guru". Conceptual relationship of linguistic form with dimensions of the socio-cultural seen in relation of meaning. That is mean linguistic patterns are always associated with patterns of socio-cultural speech community including culture that inspired the metaphors in the text of Tambo Minangkabau. the inspiration forming figurative are activity or process of acquiring knowledge and poured into Tambo Minangkabau and became a source of teaching, rule, custom, and culture. forming figurative inspiration in TM are figurative inspiration from nature, figurative inspiration from objects (tool), figurative inspiration from animals, inspiration from pattern of human bodies, and inspiration from the concept of religion.
\end{abstract}

\begin{abstract}
Abstrak
Penelitian mengenai kias dalam Tambo Minangkabau difokuskan pada kajian bentuk kias dan inspirasi pembentuk kias dalam Tambo Minangkabau. Penelitian ini bertujuan untuk menjelaskan apa saja bentuk-bentuk kias dan menjelaskan inspirasi pembentuk kias yang terdapat dalam teks Tambo Minangkabau. Berdasarkan analisis yang telah dilakukan, bentuk-bentuk kias yang teridentifikasi antara lain seperti simile, metafora, personifikasi, alegori, parabel, sinekdoke, epitet, eponim, paranomasia, dan antonomasia. Dari bentuk-bentuk kias yang teridentifikasi bentuk metafora merupakan bentuk yang paling dominan sebagai variasi penyampai cerita. Pola konsepsi masyarakat Mk dibangun melalui bentuk, sifat, dan ciri alam yang dimetaforakan ke segala aspek kehidupan untuk dijadikan pengajaran dan pandangan hidup yang dituangkan kedalam Tambo. Cara berfikir orang Mk yang bersifat metaforikal Ini merupakan perwujudan dari filosofi Alam Takambang Jadi Guru yang dianut oleh masyarakat Mk. Hubungan konseptual bentuk linguistik dengan dimensi lingkungan sosio-kultural terlihat antar hubungan makna. Artinya, pola-pola linguistik selalu berhubungan dengan pola-pola sosio-kultural masyarakat penutur, termasuk budaya masyarakat MK yang menjadi sumber inspirasi kias dalam teks TM. Inspirasi pembentuk kias ini merupakan kegiatan atau proses memperoleh pengetahuan termasuk kesadaran dan perasaan atau usaha mengenali sesuatu melalui pengalaman sendiri dan juga sebagai proses sosial, pengenalan, dan penafsiran lingkungan oleh orang Mk sebagai hasil pemerolehan pengetahuan yang kemudian dituangkan kedalam teks TM yang kemudian menjadi sumber dari pengajaran, aturan, adat, dan budaya Mk. Yang menjadi sumber inspirasi pembentuk kias dalam TM adalah inspirasi kias dari alam, inspirasi kias dari benda, inspirasi kias dari binatang, inspirasi kias dari anggota tubuh, dan inspirasi kias dari konsep agama.
\end{abstract}

Keywords: Tambo, Minangkabau, Kia 


\section{PENDAHULUAN}

Dunia realitas suatu masyarakat bahasa dibangun berdasarkan kebiasaan berbahasa mereka. Oleh sebab itu setiap masyarakat bahasa memandang dunia realitas dengan caranya sendiri (Sapir, 1949:162). Sama halnya dengan orang Minangkabau (Mk) yang juga mempunyai cara sendiri dalam mengunakan bahasa. Sesuai dengan kepribadiannya, orang Mk jarang menggunakan kata dengan makna literal, terbuka atau langsung tepat pada sasarannya.

Bertutur dengan menggunakan kias merupakan budaya berbahasa yang dimiliki oleh masyarakat Mk. Untuk menyatakan "hitam" dikiaskan dengan kata baro "bara", menyatakan ,putih" dikiaskan dengan kata tapuang "tepung", kata "empedu" untuk mengkiaskan ,pahit", atau kata tanguli ,gula merah" untuk mengkiaskan „manis" dan lain sebagainya.

Orang Mk juga cenderung mengungkapkan perasaan dengan menyalurkannya melalui pantun dan petatah-petitih. Bait-bait pendek yang digunakan untuk bercerita tentang apa saja dan isinya jauh terselubung di balik tuturan yang diujarkan dalam kiasan dan perumpamaan. Sejalan dengan itu, Anwar dalam Oktavianus (2005) menyatakan bahwa cara berfikir orang $\mathrm{Mk}$ bersifat metaforikal. Ini merupakan perwujudan dari filosofi Alam Takambang Jadi Guru yang dianut oleh masyarakat Mk.

Selain itu, prilaku berbahasa orang Mk juga cenderung berkias dengan makna yang berbanding terbalik dengan kata yang dituturkan. Sebagai contoh, di Mk seorang ibu terbiasa ketika mendengar komentar tentang anaknya "eh buruak bana anak kau ko, banci bana den mancaliek". Secara semantik ujaran tersebut bermakna ,anakmu jelek sekali, aku sangat benci melihatnya ${ }^{\text {ee }}$ Makna yang terlihat adalah makna negatif (hinaan), tetapi ujaran tersebut dimaknai orang Mk sebagai hal yang positif (pujian). Dalam konteks budaya "Buruak" (jelek) bermakna „Rancak" (bagus/cantik). Pola konsepsi masyarakat Mk seperti disebutkan di atas menurut Navis (1984:59) tampaknya dibangun melalui bentuk, sifat, dan ciri alam yang dimetaforakan ke segala aspek kehidupan untuk dijadikan pengajaran dan pandangan hidup. Selanjutnya, ajaran dan pandangan hidup itu di nukilkan ke dalam petatah-petitih, petuah, mamangan dan bidal. Salah satu bentuknya adalah Tambo Minangkabau (TM).

TM merupakan salah satu hasil karya masyarakat $\mathrm{Mk}$ yang mencerminkan watak dan prilaku berbahasa orang Mk. TM adalah suatu karya yang menceritakan sejarah (asalusul ) suku bangsa, negeri, dan adat Mk yang disebut juga oleh Djamaris (2001:151) dengan istilah historiografi tradisional, penulisan sejarah suatu negeri berdasarkan anggapan atau kepercayaan masyarakat setempat secara turuntemurun.

Orang Mk juga meyakini TM sebagai sumber dari pengajaran, aturan, adat, dan budaya Mk. Akan tetapi banyak kalangan khususnya para ahli sejarah menilai bahwa TM hanyalah sebuah cerita khayal dari orang-orang zaman dulu. Anggapan sebahagian orang yang menilai TM sebagai karya sejarah kritis yang berisi uraian tentang fakta dan peristiwa yang sungguh terjadi di Mk zaman dahulu tidak sepenuhnya benar.

Cerita di dalam TM dianggap tidak masuk akal dan tidak logis serta disampaikan dengan berbelit-belit tanpa kepastian atas apa yang ingin disampaikan. Seperti halnya Mansoer dalam Djamaris (1991) menyatakan bahwa ahli sejarah Mk merasa kecewa meneliti TM dari segi sejarah karena didalam TM hanya terdapat $2 \%$ fakta sejarah yang tenggelam dalam $98 \%$ mitologi.

Bahasa yang digunakan dalam teks TM adalah bahasa Melayu yang banyak dipengaruhi oleh bahasa Mk atau bahasa 
Melayu dialek Mk. Pengaruh bahasa Mkterlihat dari segi kosakata, morfologi, dan sintaksis dalam TM (Toorn dalam Djamaris, 1991). Stuktur bahasa yang digunakan dalam TM tidak bisa dimaknai secara literal saja, ada makna-makna lain yang tersimpan dalam bentuk kiasan dengan kode dan simbol budaya, dan juga banyak ditemukan bahasa-bahasa kias. Pemakaian kata-kata dalam TM merupakan diksi-diksi yang terdapat dalam bahasa Mk yang semu, klise, dan cenderung kabur. Orang Mk menyebutnya dengan kato bayang (polisemi) atau kato bagisah (majas). Kalimatnya bersayap mengandung beribu makna atau yang disebut dengan makna kias. Tanpa menerjemahkan dan menafsirkan menurut pengertian menurut yang diisyaratkannya, maka TM layaknya hanya sebuah cerita khayal dari orang zaman dulu. Untuk itu perlu dijelaskan seperti apakah kias yang dimaksud dalam TM tersebut? Seperti apa pula wujud kias dalam TM tersebut?

\section{METODE PENELITIAN}

Penelitian ini merupakan
penelitian kualitatif yang bersifat deskriptif. Penelitian kualitatif merupakan penelitian yang dalam kegiatannya peneliti melakukan penafsiran dalam menemukan hasil penelitian. Kegiatan penelitian ini menghasilkan temuantemuan yang diperoleh dari data-data yang dikumpulkan dengan menggunakan sarana yang meliputi; pengamatan dan wawancara, dan juga bisa mencakup pada dokumen, buku, kaset, dan video (Lawrence, 2006). Desain penelitian kualitatif bersifat fleksibel dan selalu mengalami perkembangan berdasarkan keadaan yang muncul dalam proses penelitian (Sugiyono, 2007:11).

Penelitian kualitatif sebagai sebuah prosedur penelitian menghasilkan data deskriptif berupa kata-kata lisan dan tertulis dari orang-orang dan prilaku yang dapat diamati (Bogdan dan Taylor, 1975:5 dalam Maleong, 1996:3). Sudaryanto
(1992:62) merumuskan penelitian yang bersifat deskriptif sebagai kegiatan yang disadari oleh keadaan yang sebenarnya. Dengan kata lain penelitian ini berpegang pada fakta-fakta atau fenomena yang terjadi pada penutur secara empiris dalam keadaan real sehingga bisa didapatkan varian kebahasaan sebagaimana kondisi aslinya.

Dalam penelitian ini penulis akan bertindak sebagai instrumen kunci dan menilai pembahasan serta persoalan mengenai makna kias sebagai sebuah penelitian kualitatif yang bersifat deskriptif. Persoalan bentuk khsusnya bentuk kias dalam TM merupakan persoalan yang penting dalam pengkajian mengenai TM dan Bahasa Mk. Untuk itu pembahasan mengenai hal ini patut dikaji dengan menguraikan kaidah-kaidah yang berlaku.

\section{HASIL DAN PEMBAHASAN}

Sesuai dengan pengertiannya, bahasa kias merupakan salah satu cara dalam bertutur dalam bentuk perbandingan, persamaan, sindiran, dan analogi. Penggunaan bahasa kias hampir mendominasi dalam menyampaikan cerita dalam TM. Hal ini sejalan dengan pernyataan Oktavianus (2005) yang menyatakan cara pengungkapan pikiran melalui bahasa secara khas yang memperlihatkan jiwa dan kepribadian orang Mk.

Bahasa-bahasa kias yang muncul di dalam TM memiliki wujud yang beragam. wujud yang dimaksud adalah wujud bahasa kias Mk yang mencakup gaya bahasa seperti simile, metafora, personifikasi, alegori, parabel, sinekdoke, epitet, eponim, panomasia, antonomasia. Analisis mengenai wujud bahasa kias dalam TM tidak bisa lepas dari kajian makna seperti semantik, pragmatik dan aspek-aspek lingkungan dan konteks sosial dan budaya. Hal ini berkenaan dengan gaya bahasa kias itu sendiri yang 
merupkan sebuah ungkapan atau gabungan kata yang menyatakan maknahusus, makna yang unsurunsurnya sering kali menjadi kabur dan merupakan sesuatu yang dikomunikasikan tetapi tidak diujarkan secara literal melainkan mengandung makna yang implisit. Artinya yang menjadi poin utama dalam bahasa kias adalah makna, tidak dikategorikan suatu ujaran sebagai sebuah bahasa kias apabila tidak mengandung makna yang implisit.

\section{Simile}

Simile adalah perbandingan yang bersifat eksplisit. Yang dimaksud perbandingan yang bersifat eksplisit ialah bahwa ia langsung menyatakan sesuatu sama dengan hal yang lain. untuk itu, ia memerlukan upaya yang secara eksplisit menunjukkan kesamaan itu, yakni katakata: seperti, sama, sebagai, bagaikan, laksana, dan sebagainya (Keraf, 2004:142). Simile dapat disebut juga sebagai perumpamaan yaitu cara berbahasa dengan membandingkan dua hal yang berbada tetapi diangap sama. Penanda simile dalam bahasa Mk antara lain adalah cando "seperti", bantuak „seperti",(sa) rupo „seperti", takah „seperti", sapantun „seperti", co „seperti", ibarek „ibarate, bak „bakee, umpamo „umpama".

Simile dalam TM dapat dicermati sebagai berikut:

(I) Jokok berkata dengan orang tiada tahu, bak halu pancukia duri. (K.18.10)

,jika berbicara dengan orang yang tidak tahu, seperti halu pencongkel durie

K.18.10 adalah analogi perbandingan antara „bicara dengan orang yang tidak tahue dan „bagaikan halu pencongkel duriee. Perbandingan di atas merupakan perbandingan langsung pada objek pertama yang dibandingkan.
Sehingga yang menjadi kias adalah „bagaikan halu pencongkel duriee. Secara literal "halu" merupakan sebuah alat yang digunakan untuk menubuk lesung dengan ukuran panjang lebih kurang 1-2m, dengan diameter lebih kurang $8-10 \mathrm{~cm}$. Halu biasanya terbuat dari kayu yang dibulatkan dengan bagian kedua ujungnya lebih besar jika dibandingkan dengan bagian tengah. Sementara "duri" merupakan bagian tumbuhan yang runcing dan tajam: bulu binatang yang kaku dan tajam: tulang ikan yang runcingruncing dan tajam: duri merupakan benda kecil yang tajam dan bisa menembus kulit sampai dalam daging yang menbuat sakit. Apabila seseorang tertusuk duri maka untuk menghilangkan rasa sakitnya maka duri tersebut akan dicongkel keluar dari daging. Dan sangat mustahil ketika seseorang mencongkil sebuah duri dengan sebuah halu. Hal ini mengacu pada orang yang mencari tahu kepada orang yang tidak tahu tidak akan mendapatkan solusi.

\section{Metafora}

Metafora adalah semacam analogi yang membandingkan dua hal secara langsung tetapi dalam bentuk yang singkat. Metafora juga disebut juga dengan perbandingan secara implisit tanpa penanda simile. (Keraf, 2004:139). Pembentukan kias dalam bahasa Mk yang bersifat metaforis mengalami pemindahan fitur semantis dari makna literal menjadi makna non-literal. Dalam TM wujud gaya bahasa metafora dapat dicermati sebagai berikut.

(I) Jikalau Raja itu hendak beristri, japuikkan anak bidadari ke dalam syurga, iyalah bernama Puti Siri Alam. (K.3.26)

,jikalau raja itu hendak beristri, jemputlah anak bidari kedalam surga, ialah bernama Puti Siri Alam"e

K.3.26 pada dasarnya adalah simile yang merupakan perbandingan 
yang bersifat ekspilisit. Penyataan yang langsung menyatakan sama dengan yang lainnya. Untuk itu diperlukan upaya yang eksplisit untuk menunjukan kesamaan itu.

Dengan menggunakan kata bagaikan, seperti, sama, laksana, dan lain sebagainya. Akan tetapi upaya tersebut bisa berangsur berubah menjadi metafora yang membandikan dua hal secara langsung dengan singkat tanpa menggunakan kata yang menujukan upaya menyamakan pada Simile. Pada K.3.26 terlihat perbandingan secara langsung antara ,,anak bidadari dalam syurga" dengan „Puti Siri Alam ${ }^{\text {ee }}$. Proses pembentukan kias pada K.3.26 dapat dijelaskan sebagai berikut.

Puti Siri Alam seperti anak Bidadari dalam syurga Puti Siri Alam Adalah Bidadari dari syurga

\section{Puti Siri Alam}

Bidadari dari syurga

Dari proses pembentukan kias di atas dapat disimpulkan bahwa TM ingin menyampakai bahwa Puti Siri Alam adalah seorang putri yang elok, cantik jelita bagaikan seorang bidadari dari syurga yang pantas dijadikan sebagai seorang istri raja. Bidadari menggambarkan sosok yang sangat cantik perempuan yang sangat baik dan elok.

\section{Personifikasi}

Personifiakasi merupakan gaya bahasa kiasan yang menggambarkan benda mati yang tidak bernyawa seolaholah hidup ataupun memiliki sifat seperti halnya manusia. personifikasi ini merupakan corak khusus dari metafora yang mengkiaskan barang-barang mati bertindak, berbuat, ataupun berbicara seperti manusia. sama halnya dengan simile dan metafora, personifikasi juga mengandung unsur persamaan. Bahasa kiasan membuat perbandingan suatu hal dengan yang lain. Yang menjadi hal lain pada personifikasi adalah benda-benda mati yang bertindak dan bersifat seperti manusia, ataupun juga watak manusia. yang menjadi pokok yang diperbandingkan itu seolah-olah berwujudmanusia, baik dalam tindaktanduk, perasaan, dan perwatakan manusia.

Wujud kias Personifikasi dalam TM dapat dicermati sebagai berikut.

(I) maka laut pun menyintak jauh*] (K.7.2)

„maka laut pun menyintak jauh

(II) Maka perahu itu pun bangun dari atas kalangannya] (K.17.2).

„maka perahu itu pun bangun dari atas kalangannya"

(III) Adapun perahu tadi berjalan sendirinya kepada laut dipapah $\mathrm{Si}$ Kati Muna dan Jihin si Kulambai Tunggal. (K.17.4).

,adapun perahu tadi berjalan sendirinya menuju laut di nakodai si Kati Muna dan Jihin si Kulambai Tunggale

Dari data di atas yang menjadi penanda kias adalah „menyintak" (K.7.2), „bangun" (K.17.2), „berjalan" (K.17.4). secara literal menyintak merupakan kegiatan menarik dengan cepat dan kuat seketika atau disebut juga sentak. Bangun adalah kegiatan terjaga dari keadaan tidur atau tidak sadarkan diri ataupun juga bangkit; berdiri dari duduk. Sedangkan bejalan merupakan bergerak melangkahkah kaki. Semua kegiatan tersebut merupakan kegiatan yang dilakukan oleh makluk hidup khususnya manusia, sehingga K.7.2., K.17.2., K.17.4 menjadi kias karena perahu sebagai benda mati seolah-olah hidup dan melakukan kegiatan seperti manusia.

\section{Sinekdoke}

Sinekdoke merupakan bentuk kiasan yang bermakna untuk bersamasama atau semacam bahasa figuratif yang 
menggunakan bagian atau salah satu untuk menyatkan keseluruhan ataupun sebaliknya mempergunakan keseluruhan untuk menyatakan bagian. Wujud kias pada TM dapat dicermati sebagai berikut.

(I) karena laki-laki dan perempuan itulah orang nan punya kerajaan] (K.8.10).

„karena laki-laki dan perempuan itulah orang yang punya kerajaan ${ }^{\text {ee }}$

(II) Adapun kita segala anak Minangkabau nan ditanai bumi nan disungkup langit] (K.13.4)

,,adapun kita segala anak Minangkanbau yang ditanai bumi yang di sungkup langite

(III) Janganlah kita ke minangkabau jua, segala raja-raja orang Pulau Perca lebih panjang bicara daripada kita. (K.22.9)

,janganlah kita ke Minangkabau juga, segala raja-raja orang pulau perca lebih panjang bicara daripada kita"

Yang menjadi lambang kias pada data di atas adalah „laki-laki" dan „perempuan" (K.8.10), „kita ${ }^{\text {ee }}$ K.13.4), dan segala raja-raja orang pulau perca (K.22.9). leksikon tersebut di atas menjadi kias kerena menyatakan keseluruhan dan keseluruhan menyatakan satu.

Pada K.8.10 dinyatakan bahwa yang mempunyai kerajaan adalah laki-laki dan perempuan. Secara literal makna yang terkandung adalah laki-laki dan perempuan mempunyai kerajaan. Sedangkan makna kias yang terkandung adalah tidak ada yang membedakan posisi laki-laki dan perempuan dalam kerajaan, Secara hakekatnya jenis manusia adalah laki-laki dan perempuan jadi kiasan di atas mewakili semua orang, artinya adalah kerajaan milik semua orang.

Pada K.13.4 dinyatakan kita segala anak Minangkabau yang ditanahi bumi yang disungkup langit. Secara literal „kita" mengacu pada yang berujar dan mendengar. Sedangkan makna kias yang terkandung adalah semua orang Minangkabau. Kita menjadi bagian semua yang mewakili keseluruhan orang Minangkabau, hal ini ditegaskan karena mengacu pada ucaran berikutnya yaitu "yang ditanahi bumi yang disungkup langit".

Kemudian pada K.22.9 dinyatakan bahwa janganlah kita ke Minangkabau lagi, karena semua raja-raja orang pulau perca lebih panjang bicara daripada kita. Secara literal dapat dilihat makna yang terkandung pada segala raja-raja orang pulau perca adalah orang yang panjang bicara. Sementara makna kiasnya hanyalah mengacu pada satu orang raja saja. Hal ini menjadi bentuk kias sinekdoke karena menyatakan semua untuk satu.

\section{Epitet}

Epitet atau dapat disebut juga Epitela merupakan kiasan yang menyatakan suatu sifat yang mengacu ciri-ciri seseorang atau menyatakan kesamaan ciri dari suatu hal. Ciri tersebut merupakan frasa deskriptif yang menggantikan nama seseorang, suatu barang, atau suatu keadaan. Wujud kias epitet dalam TM dapat dicermati sebagai berikut.

(I) Maka berkata segala anak Adam semuhanya, "Jika demikian kata segala malaikat, kami ikut barang katanya." (K.3.25)

„maka berkatalah segala anak Adam semuanya, "jika demikian kata segala malaikat, kami ikut dengan

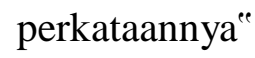

(II) lamalah pula sudah kawin maka dikeluarkan Allah Taala unggas zaman mila dari dalam syurga akan menentukan silang saluak dalam dunia. sesungguhnya unggas batinnya malaikat (K.3.48)

„setelah berapa lama menikah maka 
dikeluarkan Allah taala unggas zaman mila dari dalam syurga akan menyelesaikan silang seluk dalam dunia. Sesungguhnya unggas batinnya malaikat"

(III) Maka memandanglah ia ke
magrib tibalah antara laut
disabung ombak.(K.3.50)

„maka memandanglah ia ke magib tibalah antara laut dihempas ombak ${ }^{e e}$

Yang menjadi penanda kias pada data di atas adalah "kata segala malaikat" (K.2.25), „unggas zaman mila" (K.3.48), dan „magrib" (K.3.50). Kiasan di atas merupakan bentuk epitet karena menyatakan atau menyamakan ciri suatu hal untuk menyatakan yang lain.

$$
\text { Pada K.3.25 Analogi }
$$

pembentukan kias di atas merupakan perbandingan antara malaikat dengan ide, pikiran, ataupun ispirasi manusia dalam proses berfikir. Malaikat merupakan sesosok yang diciptakan oleh Allah berupa dzat yang abtsrak dan tidak mempunyai hawa nafsu yang bertugas membantu Tuhan (Allah) dan menjalankan perintah seperti menyampaikan wahyu, mencatat amal baik dan buruk, meniup terompet, dan lain sebagainya. Sementara ide, pikiran, ataupun inspirasi merupakan hasil kerja atau proses kerja otak manusia. akan tetapi karena proses kepercayaan (agama) yang dianut dalam sosio kultural masyarat Mk yang meyakini bahwa ada suatu hal yang abstrak yang mempengaruhi pikiran, ide, maupun inspirasi dalam otak manusia, sehingga ide, pikiran, ataupun inspirasi tersebut dianggap datang atau disampaikan oleh hal yang bersifat abstrak dan bukan hanya proses dari kerja otak manusia saja dalam hal ini adalah malaikat sebagai penyampai berita atau wahyu.

Pada K.3.48. proses pembentukan kias adalah analogi perbandingan antara ungas zaman mila dengan anak manusia. Dari data di atas dapat dicermati ujaran "setelah berapa lama menikah maka Allah mengeluarkan unggas zaman mila untuk menyelesaikan masalah di dunia". Dari situ dapat dilihat "dikeluarkan unggas" melahirkan seorang anak. dalam mitologi masyarakat $\mathrm{Mk}$ unggas zaman mila adalah burung yang dapat berkata-kata (bijaksana) (Djamaris, 1991: 267). Artinya unggas zaman milla adalah seorang yang akan menjadi pemimpin yang akan menyelesaikan masalah dunia dalam hal ini adalah dunia Mk.

Kemudian data K.3.50 merupakan kias yang menganlogikan antara magrib dengan barat. Magrib berasal dari bahasa Arab yang berarti sore atau matahari tenggelam. Analogi pembentukan kias adalah perbandingan antara sore (magrib) dengan wilayah geografis barat. Proses ini merupakan penyamaan keadaan sore yang sudah gelap saat matahari tenggalam dengan kepercayaan sembahyang (sholat) disore dalam agama Islam yaitu magrib. Mengacu pada ujaran "maka memandang ia kearah magrib diantara laut disabung ombak", makna magrib berarti adalah barat karena kondisi sore adalah pada kondisi matahari mulai tenggelam . Sedangkan dari pandangan geografis arah atau wilayah matahari tenggelam adalah wilayah barat, sehingga makna yang terkandung pada magrib diartikan sebagai barat, hal ini juga dihubungkan dengan tempat yang menjadi kiblat shalat umat Islam di Madinah, yang tadinya menghadap ke barat, yaitu ke Baitul Maqdis, dan ke timur, yaitu ke Ka'bah, Kota Suci Makkah.

\section{Eponim}

Eponim adalah suatu gaya bahasa atau bentuk kias yang menghubungkan nama seseorang dengan sifat tertentu ataupun hal lain, sehingga nama atau istilah tersebut dipakai untuk menyatakan sifat atau sebuah acuan yang merujuk pada sesuatu. Berikut data dalam TM yang menggunakan wujud eponim.

(I) Maka segala malaikat- malaikat 
pergi kepada anak Adam itu. (K.3.15)

„maka segala malaikat-malaikat pergi kepada anak Adam itue

(II) Maka malaikat itu pun menurunkan anak Adam itu kepada bumi yang suci antara Pasirik dan Pasirung] (K.3.20),

„maka malaikat itu pun menurunkan anak Adam itu ke bumi yang suci antara Pasirik dan Pasirung

(III) Itulah nan $k a$ jadi angkatangkatan sembah (kepada anak Adam itu semuhanya)] (K.3.22).

,itulah yang akan jadi sesembahan (kepada anak Adam itu semuanya) ${ }^{\text {ee }}$

Nama yang sering diungkapakan menjadi sumber inspirasi kias dalam TM adalah „Adam“e. Menurut pemahaman Islam Adam adalah manusia yang diyakini sebagai manusia pertama yang ada dibumi di bumi kemudian Hawa sebagai pendampingnya. AlQuran memuat kisah Adam dalam beberapa surat, di antaranya $A l$ Baqarah 30-38 dan Al-A"raaf 11-25. Dalam gambarannya adam adalah makhluk yang teramat cerdas, sangat dimuliakan oleh Allah, memiliki kelebihan yang sempurna dibandingkan makhluk yang lain sebelumnya dan diciptakan dalam bentuk yang terbaik hal ini digambarkan dalam Surah Al Israa' 70. Begitu juga halnya dengan Mk yang juga meyakini bahwa semua manusia yang ada di muka bumi merupakan anak cucu adam.

Penggambaran Adam sebagai manusia pertama dan semua manusia sebagai keturunannya menjadi sumber inpirasi kias yang mengacu pada seseorang yang bukan Adam dalam arti yang sebenarnya melainkan orang yang dianggap sebagai keturunan dari adam. Sehingga makna "anak adam" yang dinyatakan dalam TM adalah seseorang yang lain dan bukanlah anak Adam yang sesungguhnya (anak kandung) melainkan anak-anak garis keturun Adam atau bisa dimaknai sebagai manusia. Artinya adalah ,anak Adam"e dikiaskan atau kata ganti dari ,manusia ${ }^{e e}$.

Selain „Adam", nama atau istilah lain yang sering untuk mengungkapan dengan wujud gaya bahasa kias Eponim dalam TM adalah „Bidadariee. Bidadari adalah pengaruh Islam yang menggambarkan sesosok yang sangat cantik perempuan yang sangat baik dan elok atau putri ataupun dewi dari kayangan (syurga). Dalam al-quran ada skitar 8 kelompok ayat yang menyinggung mengenai bidadari diantaranya QS 44 : 54 , QS 52 :20, QS

56 : 22-23, QS $37: 48-49$, QS 38 : 52, QS $55: 56$, QS $55: 70$, dan QS $56: 36-37$ (Al-qSED.V.0.1). Berikut berapa data dalam TM yang menyatakan bidadari.

(I) Maka tiba-tiba di dalam syurga didapatinya anak bidadari itu sedang bertenun kain sangsita kala namanya] (K.3.28).

„maka tiba-tiba di dalam syurga didapatinya anak bidadari itu sedang bertenun kain Sangsitakala namanya"

\section{(II) Maka berkata malaikat kepada anak bidadari itu, (K.3.29)}

„maka berkata malaikat kepada anak bidadari itu $^{\text {ee }}$

\section{(III) Maka segala anak-anak bidadari pun menari,] (K.3.34)}

„maka segala anak-anak bidadaripun menarie

Dari data-data dalam TM di atas dapat dicermati bahwa leksikon „bidadari“ merupakan kiasan untuk tokoh wanita, hal ini berhubungan dengan status wanita di Mk yang menjadikan wanita sebagai sosok yang mulia. Kedudukan dan peranan perempuan itu sangat besar dan sangat diharapkan keberadaannya. Adat Minangkabau sejak dulu mendudukkan perempuan pada sisi yang besar. Peranan 
perempuan terlihat pada asas Sistem Kekerabatan Matrilinial (SKM) di Mk. Nenek moyang orang Minang sudah

\section{Paronomasia}

Paronomasia adalah semacam gaya bahasa atau bentuk kiasan yang menggunakan kemiripan bunyi yang merupakan permainan kata yang disarkan pada permainan bunyi atau kemiripan bunyi, tetapi terdapat perbedaan besar dalam maknanya. Wujud kias berupa paronomasia dalam TM dapat dicermati sebagai berikut.

(I) Adapun penghulu empat perkara: pertama penghulu namanya, kedua peghala namanya, ketiga pengaluh namanya, keempat pengalih namanya (K.8.14).

,adapun penghulu ada empat perkara: pertama Pengulu namanya, kedua pengala namanya, ketiga pengaluh namanya, keempat pengaluh namanya"

(II) Arti penghulu memelintahkan segala kaumnya seperti nabi kasih kepada segala umatnya (K.8.15)

,,arti penghulu memerintahkan semua kaumnya seperti kasih nabi kepada seluruh umatnya"

(III) arti pengalah, jikalau kata benar sekalipun disalahinya juga (K.8.16)

,arti pengalah, jikalau bernar sebuah perkataan akan disalahkan juga"

(IV) artinya pengaluh, kuat menyuruhkan orang berbuat jahat (K.8.17)

,arti pengaluh, kuat menyuruhkan orang berbuat jahat"

(V) arti pengalih, kuat menyuruhkan orang berbuat maksiyat dalam negeri (K.8.18).

„arti pengalih, kuat menyuruhkan orang berbuat maksiat dalam negeri"e

Dari data di atas dapat diliahat permainan kata yang merupakan wujud beretetapan hati menghitung garis keterunannya berdasarkan garis keturunan ibu (Sfafnir, 2006:56).

dari gaya bahasa kias Paronomasia yang setiap kata secara bunyi hampir mendekati sama secara fonologis, akan tetapi memiliki makna yang jauh berbeda sama sekali. Selain itu data berikut juga merupakan contoh lain bentuk kiasan dalam TM dengan bentuk kias Paronomasia.

(VI) Adapun kita segala anak Minangkabau nan ditanai bumi nan disungkup langit] sedikitpun tiada lebih, sedikitpun tiada kurang Jika dikata lebih ada kurangnya, jika dikata kurang ada lebihnya (K.13.5).

,adapun kita semua anak Minangkabau yang ditanahi bumi dan disungkup langit, sedikitpun tiada kurang. Jika dikatakan lebih ada kurangnya, jika dikatakan kurang ada lebihnya"

\section{(VII) jika dikata rendah ada tingginya, jika dikata tinggi ada rendahnya (K.13.6).}

,jika dikatakan rendah ada tingginya, jika dikatakan tinggi ada rendahnya"

Jika dicermati, data di atas tidak bisa dimaknai secara literal karena makna yang terkandung tidak jelas dan bertentangan satu dengan yang lainnya atau disebut juga dengan kalimat yang bermakna rancu. Makna kias yang terkandung pada K.13.5 adalah segala sesuatu yang sudah pas atau cocok. Jika dicermati arti kata di atas adalah dikatakan lebih ia tidak lebih karena ada kurangnya, dan juga jika dikatakan kurang ia tidak kurang karena ada lebihnya.

Sedangkan makna kias yang terkandung pada data K.13.6 juga segala sesuatu yang sudah pas atau cocok. Jika dicermati arti kata di atas adalah dikatakan rendah tetapi ia tidak rendah kerena ada tingginya, dikatakan tinggi ia 
pun tidak tinggi karena ada rendahnya, artinya makna kias pada K.13.6 dan K.3.6 adalah tidak ada kurang dan tidak ada lebih, dtidak ada tinggi dan juga tidak ada rendah atau bisa disebut juga dengan biasa-biasa saja atau sudah pada porsinya.

Makna kias tersebut mengacu kepada manusia atau masyarakat $\mathrm{Mk}$, hal ini merujuk pada sosio - kultural masyarakat Mk yang tidak membeda-beda satu dengan yang lainnya atau dengan kata lain masyarakat $\mathrm{Mk}$ tidak mengenal kelas sosial yang membedakan manusia satu dengan lainnya.

\section{Antonomasia}

Antonomasia merupakan bentuk khusus dari sinekdoke yang berbentuk penggunaan sebuah epitet untuk menggantikan nama, nama diri, gelar resmi, jabatan, dan lainnya. Wujud gaya bahasa kias Antonomasia yang terdapat dalam TM adalah sebagai berikut.

(I) pakaian orang besyar-besyar dan segala raja-raja. (K.1.4)

„pakaian orang besar-besar dan segala raja-raja"

(II) Maka takala sumur akan dikali negeri akan diacak medan akan dihiasi akan tempat perhimpunan orang kaya-kaya dan orang besyarbesyar dan orang mulia-mulia dan raja yang mahaadil, itulah kebesaran raja dan penghulu. (K.6.2)

„maka dikala sumur akan digali, negeri akan diacak, medan akan dihiasi untuk perhimpunan orang kaya-kaya dan orang besar-besar dan orang-orang mulia-mulia dan raja yang maha adil, itulah kebesaran raja dan pengulu ${ }^{\text {ee }}$

(III) Jika dikata raja tinggi-tinggi dan orang besyar-besyar itu lebih daripada lainnya, terlalu rendah batinnya karena hanya maisi lembaga alam kepada tiap-tiap luak, laras atau kepada negeri. Itulah rendahnya. (K.13.7)

,jika dikata raja tinggi-tinggi dan orang besar-besar itu lebih daripada yang lain, terlalu rendah batinnya karena hanya mengisi lembaga alam kepada tiap-tiap luhak, laras atau kepada negeri. Itulah rendahnya"

Yang menjadi kias pada data di atas adalah "orang besyar-besyar". Secara literal orang besar mearti orang yang memiki badan besar atau tidak seperti ukuran manusia pada umumnya. Orang besar-besar merupakan bentuk kias antonomasia karena menggantikan nama atau gelar, dalam hal ini adalah pengulu. Hal ini mengacu pada konsep pengulu sebagai pemimpin. pemimpin dalam konsepsi masyarakat $\mathrm{Mk}$ adalah orang yang dipilih dalam kerabat mereka, yaitu yang terbaik dari segi kualifikasi yang ditentukan oleh adat. Pengulu diberikan kekuasaan dan kebesaran seperti dalam istilah Mk penghulu itu "digadangkan makonyo gadang "dibesarkan makanya besar"e, Tumbuahnyo di tanam"tumbuhnya ditanam", Tingginya dianjuang "tingginya dianjung", Gadangnyo diamba "besarnya diamba" (Nasroen dalam Amir Stj). Maksudnya, jabatan penghulu itu diperoleh oleh seseorang karena diangkat oleh anggota kaumnya sendiri. Tingginya dianjung, besarnya dipelihara, dengan pengertian sebelum dia diangkat dan memegang jabatan penghulu, dia sudah besar dan tinggi serta dihargai di dalam kaumnya.

Selain data K.1.4, K.6.2, dan K.13.7 berikut adalah contoh lain yang terdapat dalam TM dengan bentuk kias Antonomasia.

\section{(IV) Dan pikirkan bersungguh-sungguh di dalam hati supaya jan kanai}




\section{sumpah sati niniak kita Nabi Allah Adam alaihisalam. (K.18.4).}

„dan pikirkan bersungguh-sungguh di dalam hati supaya jangan kena sumpah sakti nenek kita Nabi Adam alaihisalam"e

Yang menjadi ungkapan kias pada data di atas adalah kata „nenek ${ }^{e}$. Kata „niniak ${ }^{\text {ee }}$ merupakan padanan kata „,nenek yang berarti ibu dari orang tua (ibu dan ayah) atau secara luas adalah orang yang tua. Kata niniak pada K.18.4 bermakna dengan wujud gaya bahasa kias Antonomasia karena menggantikan atau mengacu pada Nabi Alla Adam Alaihiwasam. Analogi ninik pada Adam mengacu pada keyakinan Adam sebagai manusia pertama di bumi dan seluruh umat manusia yang ada di bumi merupakan anak cucunya.

\section{SIMPULAN}

Tambo Minangkabau

(TM) merupakan salah satu hasil karya masyarakat Minangkabau yang mencerminkan watak dan prilaku berbahasa orang Minangkabau (Mk). TM adalah suatu karya yang menceritakan sejarah asal-usul suku bangsa, negeri, dan adat Mk yang disebut juga dengan istilah historiografi tradisional, penulisan sejarah suatu negeri berdasarkan anggapan atau kepercayaan masyarakat setempat secara turun-temurun. Orang Mk meyakini TM merupakan sumber dari pengajaran, aturan, adat, dan budaya Mk.

TM merupakan refleksi budaya berbahasa orang Mk. Wacana yang dapat berwujud teks media, pepatah, pribahasa, cerita rakyat yang merupakan produk bahasa yang mencerminkan bahasa sebagai sumberdaya yang memiliki bentuk dan makna tersendiri yang sebahagian besar disampaikan dalam bahasa kias. Bentuk-bentuk kias yang terdapat dalam teks TM antara lain adalah simile, metafora, personifikasi, alegori, parabel, sinekdoke, epitet, eponim, paranomasia, dan antonomasia.

Kias sebagai salah satu bentuk linguistik dalam teks TM memiliki aspekaspek kompleks yang menggambarkan pola-pola sosio-kultural masyarakat $\mathrm{Mk}$ sendiri. Kias-kias tersebut memiliki makna dan nilai-nilai sosio-kultural dan sosio-ideologis yang berlapis dan perlu dibedah secara interteks dan kritis. Artinya, pola-pola linguistik selalu berhubungan dengan pola-pola sosiokultural masyarakat penutur, termasuk budaya masyarakat MK yang menjadi sumber inspirasi kias dalam teks TM. Inspirasi pembentuk kias ini merupakan kegiatan atau proses memperoleh pengetahuan termasuk kesadaran dan perasaan atau usaha mengenali sesuatu melalui pengalaman sendiri dan juga sebagai proses sosial, pengenalan, dan penafsiran lingkungan oleh orang $\mathrm{Mk}$ sebagai hasil pemerolehan pengetahuan yang kemudian dituangkan kedalam teks TM yang kemudian menjadi sumber dari pengajaran, aturan, adat, dan budaya Mk. Yang menjadi sumber inspirasi pembentuk kias dalam TM adalah inspirasi kias dari alam.

Semua itu bentuk dan inspirasi pembentuk kias dalam TM merupakan sefleksi dari prilaku berbahasa orang $\mathrm{Mk}$. Pola konsepsi masyarakat $\mathrm{Mk}$ dibangun melalui bentuk, sifat, dan ciri alam yang dimetaforakan ke segala aspek kehidupan untuk dijadikan pengajaran dan pandangan hidup yang dituangkan kedalam TM. Cara berfikir orang $\mathrm{Mk}$ yang bersifat metaforikal Ini merupakan perwujudan dari filosofi Alam Takambang Jadi Guru yang dianut oleh masyarakat Mk.

Teks TM awalnya berbentuk teks lisan yang dikomunikasikan dalam tradisi 
lisan masyarakat Mk (kemudian dituliskan tengan bahasa melayu tenggi). Oleh karena itu kontruksinya mengikuti Prinsip dan kaidah bahasa lisan. Prinsip bahasa lisan Mk merupakan bahasa yang mengutamakan aspek keindahan dan interaksi. Keindahan yang dimaksud adalah bahasa-bahasa yang bersifat metaforik atau kias dengan makna konotatif. Hal ini sejalan dengan ungkapan filosofis orang $\mathrm{Mk}$ yang menyatakan "Manusia tahan kias, binatang tahan palu". Oleh karna itu memahami TM harus berdasarkan kaidahkaidah budaya berbahasa orang Mk.

Tanpakanya pernyataan ahli sejarah yang menyatakan TM merupakan cerita khayal orang zaman dahulu yang berisikan 98\% dongeng yang dibalut dengan $2 \%$ persen sejarah perlu dikaji ulang. Hal ini bukan masalah bukti sejarah dan fakta-fakta logis melainkan aspek-aspek sosio-kultural masyarakat Mk dalam menggunakan bahasa.

\section{DAFTAR PUSTAKA}

Bungin, Burhan. 2006. Sosiologi Komunikasi. Jakarta: Kencana Prenada Media Group.

Chaer, Abdul. 1995. Sosiolinguistik: Perkenalan Awal. Jakarta: Rhineka Cipta.

Chaer, Abdul dan Leonie Agustina. 2004. Sosiolinguistik. Jakarta: Rhineka Cipta.

Chika, Elaine. 1982. Language the Social Mirror. USA: Newbury House Publishers. INC.

Culler, Jonathan. 1996. Saussure. Terj Rochayah. Jakarta: Pusat Pembinaan dan Pengembangan Bahasa.

De Saussure, Ferdinand. 1959. Course in
General Linguistics. New York: Philosophical Library.

Djamaris, Edwar. 2001. Pengantar Sastra Rakyat Minangkabau. Jakarta: Yayasan Obor Indonesia.

Djamaris, Edwar. 1991. Tambo Minangkabau. Jakarta: Balai Pustaka.

Duranti, A. 1997. Linguistik Anthropology. Cambridge: Cambridge University Press.

Foley, William A. 1997. Anthropological Linguistic. Oxford: Blackwell.

Keraf, Gorys. 2004. Diksi dan Gaya Bahasa. Jakarta: PT. Gramedia Pustaka Utama.

Kraamsh, Claire. 1998. Language and Culture. Oxford: Oxford University Press.

Lakoff, G. 1994. Metaphors We Live By. Chicago: The University of Chicago press.

Nababan, P.W.J. 1994. Sosiolinguistik: Suatu Pengantar. Jakarta: Gramedia.

Nurdin, Ade, Yani Maryani, Mumu. 2002. Bahasa Indonesia: Pengantar. Jakarta: Perpustakaan Nasional.

Oktavianus. 2005. Kias dalam Bahasa Minangkabau. (Disertasi) Denpasar: Universitas Udayana.

Ortony, A. 1981. Metaphor and Thought. Cambrige University Press.

Palmer, F.R, 1976. Semantics: A New outline. Cambridge University Press.

Ricour, P. 1977. The Rules of Metaphor. London: Routledge \& Kegan Paul.

Sapir, E. 1949. Language. New York: Harcourt and Brace.

Sjarifoedin, Amir. 2011. Minangkabau: 
Dari Dinasti Iskandar Zulkarnain sampai Imam Bonjol. Jakarta. PT. Citra Media Perkasa.

Sibarani, Robert. 2004. Antropolinguistik. Medan: Penerbit Poda.

Wardhaugh, Ronald. 1986. An Introduction to Sosiolinguistics. New York: Basil Blackwell. 